\title{
The Pearson Report-compromise or step towards effective and just compensation for disability?
}

\author{
J. M. COLLINSON
}

From the Faculty of Law, The University, Newcastle upon Tyne NE1 7RU

ABSTRACT The setting up of the Royal Commission on Civil Liability and Compensation for Personal Injury, its terms of reference and report are discussed. The main recommendations are detailed with brief consideration of their possible impact. The proposals are assessed and the philosophy and principles behind the reform, explicit or implicit in the Report, are considered. Finally, the extent to which the proposals can be a blueprint for later reforms dealing with compensation for disability in general is discussed.

The Report of the Royal Commission on Civil Liability and Compensation for Personal Injury (the Pearson Commission) was published in March, $1978^{* 1}$ after the Royal Commission had worked for five years on the problems in this field of the law. Volume 1 deals with the issues involved in compensating for personal injuries, detailing the proposals of the Commission for reform. Volume 2 gives the statistics and costings and includes statistical information based on a household survey. Volume 3 is a comparative study of systems of compensation in other countries. To enable the Commission to examine the many different compensation systems in existence or under discussion, groups of Commissioners visited a variety of countries, including Canada, the United States of America, Australia, New Zealand, Switzerland, France, the Federal Republic of Germany, the Netherlands and Sweden. They also visited the International Labour Office at Geneva, the Commission of the European Communities at Brussels and the Secretariat of the Council of Europe at Strasbourg.

Received for publication 23 January 1979

Accepted for publication 9 May 1979

\section{The Setting Up of the Commission and its Terms of Reference}

The Commission was set up in 1973 after the Report of the Robens Committee on Safety and Health at Work, at a time when there was also much public concern over whether, and by whom, compensation should be paid to children born handicapped as a result of their mothers having taken the drug thalidomide at a vital stage of the pregnancy. The terms of reference of the Commission required them to consider to what extent, in what circumstances and by what means compensation should be payable 'for death or personal injury suffered in five specified circumstances: (a) in the course of employment; (b) through the use of a motor vehicle or other means of transport; (c) through the manufacture, supply or use of goods or services; (d) on premises belonging to or occupied by another; or (e) otherwise through the act or omission of another where compensation under the present law is recoverable only on proof of fault or under the rules of strict liability'. ${ }^{2}$ The Commission interpreted their terms of reference in such a way as to exclude property damage, loss not resulting from death or personal injury, and illness resulting neither from injury nor

*The members of the Commission were: Lord Pearson, former Lord Appeal in Ordinary; Lord Allen of Abbeydale, former permanent Under-Secretary of State, Home Office; Lord Cameron, Senator of the College of Justice in Scotland; Mr Walter Anderson, former General Secretary, National and Local Government Officers' Association; Professor Norman Marsh, QC, former Law Commissioner; Professor Richard Schilling, former Professor of Occupational Health, London School of Hygiene and Tropical Medicine; Mr Ronald Sherman, Chief Actuary, Prudential Assurance Company; Mrs Margaret Brooke, former Vice-Chairman, National Federation of Women's Institutes; Professor Robert Duthie, Nuffield Professor of Orthopaedic Surgery, Oxford University; Mr Robert MacBrindle, QC; Mr Denis Marshall, solicitor, member of Council, Law Society; Professor Alan Prest, Professor of Economics, London School of Economics; Mr A. Sansom, Managing Director, Iron Trades Employers' Federation (retired); Professor Olive Stevenson, Head of Department of Social Policy and Social Work, Keele University; Mr James Stewart, WS; Mr Alan Ure, Director, Trollope and Colls. 
occupational in origin, thereby excluding injury suffered at home or in pursuit of leisure. The Report states that 'the terms of reference clearly do not envisage as immediately practicable a comprehensive scheme dealing with all injuries, still less a universal scheme dealing with all incapacity whether caused by injury, disease or congenital defect ${ }^{3}$.

One can criticise this standpoint in that, even within these terms, the Commission were unduly restrictive. In any case, terms of reference are intended as guidelines only, not a strait-jacket: they are intended to show the main problem to be looked at, but without necessarily excluding problems, which on close examination are then seen not only to be relevant, but inextricably linked with the main problem. The Commission itself exceeded its terms of reference by recommending the introduction of a new benefit for severely handicapped children, the extension of the industrial scheme to new examples of occupational illness and certain changes to the present social security system (e.g. mobility allowance). They also urged the Government to reconsider the entitlement to widows' benefit and the treatment of the partially disabled, neither of which can be said to be within the terms of reference. It was also open to the Commission to look at the wider issues even if these exceeded their terms of reference, if they felt that any recommendations within their original terms would be unsatisfactory without paying attention to the wider issues. The Woodhouse Commission (Report of the Commission of Inquiry into Compensation for Personal Injury in New Zealand), looking at the same problem, refused to interpret its terms of reference in a restrictive way, ${ }^{4}$ because it felt the need to examine the problem of compensation for disability in its widest context. It was thus able to pursue its enquiries in a much more far-reaching manner and to make more sweeping recommendations.

Because any legislation brought into force as a result of the recommendations of the Pearson Commission would not be limited in any way to these terms of reference, and because so many are agreed that some reform in this area is necessary, it would surely have been better if the Commission had been prepared to look at the whole area, by refusing to interpret its brief so restrictively. If it really felt that it could not interpret it more widely, it could still have looked at all the issues on the basis that it could not do its job properly without considering these, and without seeing how these were affected by any recommendations made. The Report could then have been framed accordingly.

The Commission decided that the terms of reference precluded it from considering accidents which occur in a person's own home and are not due to acts or omissions of another person, although this is far from clear from the terms themselves, as the majority of accidents occurring in the home in fact occur on 'premises belonging to or occupied by another', heading (d) of the terms of reference. An accident victim is often a member of the family of an owner or occupier of a house, or he may be a tenant rather than the owner of a house.

\section{The Main Recommendations}

\section{THE TORT ACTION}

Throughout the Report the Commission appear to feel that they are recommending a system preferable to the present action in tort, yet they felt unable at that stage to recommend its abolition, in whole or in part. The decision on retaining the action in tort is argued very briefly. ${ }^{5}$ Although the Report does not recommend its abolition, a number of modifications are proposed and a shift in emphasis to an improved social security scheme, so that in future tort should play a minor role compared to that of social security. Whether it will have this effect in practice is, however, by no means certain. The main modifications proposed are as follows:

(a) The ending of double compensation. It is recommended that social security should be fully offset against the assessment of the corresponding tort damages instead of $50 \%$ of these benefits for up to five years, as at present. ${ }^{6}$ This would prevent the present double or overlapping benefit, for which the Commission could find no justification, a step with which few would disagree.

(b) Inflation-proofed periodic payments. It is recommended that damages should normally take the form of inflation-proofed periodic payments in the most serious cases; the court being obliged to award periodic payments in such cases, unless satisfied that a lump sum was more appropriate. ${ }^{7}$ This part of the Report was not unanimous, there being two dissenting opinions. Because an injured person would still be at liberty to settle his claim by agreement, and as Insurance Companies are almost certain to offer any settlement in the form of a lump sum for administrative convenience, this will introduce one further element into weighing up whether to settle or fight in court. If one pursues a case to Court, even if successful, the damages awarded would probably not be in the form of a lump sum as they would be if one settled, and the Insurance Companies might well use this as a further bargaining counter to obtain slightly lower settlements. The Commission feel that Insurance Companies ought not to be compelled to make settlements in the form of periodic 
payments, but hope that they might find encouragement to do so if the awards in Court were made in this form. This seems likely to be an unrealistic hope as many people prefer a lump sum, however desirable periodic payments are in some ways. Such a claimant is likely to be influenced by the argument that he should accept what the Insurance Company offers (because anything higher, awarded in Court would not normally be in the form of a lump sum) even if his professional adviser fulfils the duty of pointing out the advantages of periodic payments, as is suggested by the Commission.

(c) Elimination of certain minor claims. It is recommended, with one dissent, that there should be a three-month time-threshold for damages for non-pecuniary loss. ${ }^{8}$ This would result in a saving of money from the compensation itself and administrative expenses, no damages being awarded for pain and suffering and loss of amenity in the first three months after the occurrence of the injury. While accepting that this would save money, any other justification for it is not immediately clear. It is quite possible for someone to suffer pain for less than three months which is nevertheless very severe and hard to bear while it lasts. It is by no means self-evident that such a person is a less deserving case for compensation in respect of the pain than a person with much less severe pain which lingers on for six months. Arguments can be put in favour of never awarding compensation for pain or suffering. ${ }^{9}$ It can also be argued that no compensation should be awarded for any loss for a short period, on the basis that this would save money which could then be used for compensation for longer periods of disability, and that most people can cope with a drop in income for a short period. The distinction in the Report is less easy to justify. It is clearly easier to justify no award for loss of amenity for a short period, in that one can bear that for a short time, especially if the loss is slight, while if it were substantial it would be likely to continue after three months, when it would be compensatable.

(d) Changes in the assessment of damages. It is recommended that fuller account should be taken of the effects of tax and inflation in assessing the plaintiff's loss. ${ }^{10}$ However, there was a minority view expressed here by several of the Commissioners to the effect that a lump sum was different in kind from a lost income, and that regard should be paid to this in assessing it to ensure that a plaintiff was not over-generously treated, especially as inflation over a large number of years was a matter of conjecture.

\section{Effect of These Proposals}

The proposals for fully off-setting social security benefits against damages, and for abolishing damages for pain and suffering for the first three months, if fully implemented, would eliminate a large number of tort claims. Approximately $95 \%$ of all injured make sufficient recovery within three months to be able to resume work, even if they have residual disabilities. This might, therefore, cut the total number of tort claims substantially and some of the Commissioners clearly envisaged a gradual withering away of the law of tort as a result of this. The proposed improvements in the long-term social security benefits for victims of road or work accidents will result in many low or average earners receiving benefits close to their actual loss of earnings. Because these benefits are to be deducted from any damages awarded in a tort claim, such persons would have little to gain from pursuing an action in the Courts. For the higher earner, however, much could still be gained from a claim in tort.

The suggested improvements in the method of assessing damages for future loss of earnings would particularly benefit the higher-than-average earner, because of the inflation-proofing proposal. The nofault benefits proposed would leave him with a much larger loss of income not covered, and so, even with the off-setting process, he would still be left with quite a large drop in income, which he might seek to recover in a tort action.

\section{Strict Liability}

The imposition of strict liability is proposed for certain cases:

(a) Vaccine-damaged children. The Commission appears to have changed their mind on this in succeeding paragraphs. ${ }^{11}$ One cannot but wonder at yet another special group being singled out for priority in the field of compensation. However beneficial for the sufferers themselves and their families, the cause of disablement as a whole surely requires equal treatment. The problems of all children who are handicapped, and of their families, are similar, whether the damage be due to vaccine, to injury during or before birth from whatever cause, or to handicapping, from whatever cause, in childhood. The Commission itself admits this. One cannot help feeling that it is a further example of a pressure group being sufficiently vocal, so that reformers and Governments are persuaded, with good intentions, of the need for alleviating hardship or injustice without examining the main problem to see if it is equally unjust to single out such a group for preferential treatment when others are equally deserving. While medical knowledge is not yet able 
to show the cause of all such disabilities, there may well be other causes operating in Society generally which at least contribute to such. Even with vaccine damage itself it is very difficult to determine whether a person really has suffered damage as a result of the vaccine. The Commission attempt to justify the discrimination on the basis that vaccination is really done to protect the community. Although the community does benefit indirectly, parents who agree to vaccination do so in the hope of protecting their own child, and, if they know of the risks, weigh these up with or without the help of doctors, with little intention of benefiting the rest of the community.

(b) Defective products. The imposition of strict liability for defective products is recommended, the proposed scheme to be broadly in line with the Council of Europe Convention and the EEC draft directive**.12 It is proposed that both producers of finished products and component producers be liable, but not general distributors, and that importers should be treated as producers. No financial limit is to be placed on the liability and it should not be a defence for a producer to prove that he had withdrawn his product. The liability is to be subject to a cut-off period of ten years from circulation of the product. No special defence is to be allowed for development risks and no special treatment is recommended for the pharmaceutical industry, despite their pleading for such.

(c) Research or clinical trials. The Commission recommend that strict liability should be imposed on any authority to whom a volunteer for research or clinical trials has consented to make himself available and who suffers severe damage from these trials. ${ }^{13}$

(d) Movement of rolling stock. The introduction of strict liability is proposed for injuries caused by the movement of rolling stock, but not in respect of liability to trespassers. ${ }^{14}$

(e) Exceptional risks. The Commission recommend that some provision should be made for exceptional risks, proposing that strict liability should be imposed on controllers of things or operations (a) which, by their unusually hazardous nature require close, careful and skilled supervision because of their potential for causing death or personal injury and (b) those which although normally safe might cause serious and extensive casualties if they did go wrong. ${ }^{15}$ Category (a) would cover, for example, explosives and flammable gases or liquids, while (b) would cover large public bridges, dams, major stores and stadiums and other buildings where large numbers may congregate. They propose a statutory scheme under which certain things and operations would be listed in a statutory instrument, the controller of each becoming strictly liable for death or personal injury resulting from its malfunctioning.

No criterion is given in the Report by which one can test whether an article has an unusually hazardous nature. It would appear that it could even include motor vehicles and industrial machinery, but obviously from the Report it was not intended to include such, although these certainly have potential for serious harm if not under 'close, careful and skilled' supervision. Personal injuries often result from the use of such because their operators are either careless, reckless or insufficiently skilled. The examples given in the Report of explosives and flammable gases differ from such only in that they are most commonly operated or supervised by highly skilled persons; in other respects they are no more nor less likely to cause harm.

The second category is certainly going to give rise to a differential liability as the Commissioners themselves saw. ${ }^{16}$ If part of a bridge collapses and X is injured there would be strict liability (provided that the bridge was held to be a large public bridge) but if $\mathrm{X}$ tripped on some part of the bridge which protruded, and if he fell, injuring himself or if the bridge was held not to be sufficiently large, he would have to prove fault. Any fire in a large building could be said to be potentially serious. It might be possible to argue that injuries suffered in a fire in a public building where large numbers of people congregate (e.g. school, shop, hospital, factory) could give rise to a claim under strict liability. This would be so even if the accident was caused by a negligent, criminal or malicious act of a third party, as this is to be no defence. ${ }^{17}$

The potential of this particular provision cannot have been realised, for it could increase strict liability litigation considerably, although the Commission themselves saw it more as a tidying-up operation. The Commission do not put forward any

\footnotetext{
**European Convention on products liability in regard to personal injury and death known as the 'Strasbourg Convention', adopted by the Committee of Ministers of the Council of Europe, Strasbourg at the session of 20-29 September 1976, open for signature on 27 January 1977.

Proposal for a Council Directive relating to the Approximation of the Laws, Regulations and Administrative Provisions of the member states concerning liability for Defective Products (presented by the Commission to the Council on 9 September 1976).
} 
justification for extending strict liability in a field where hitherto it has played a negligible role.

\section{Effect of these proposals}

Apart from the abolition of the fault ingredient of liability, strict liability remains as before, liability in tort, with all the normal requirements of such an action and all the hazards, costs and delays of litigation. The usual defences to such an action will be available and, because the legislation necessary to implement such proposals will be extremely complex, with difficult borderlines created, there will be ample scope for defendants to fight claims even if more claims can be made.

\section{WORK INJURIES}

The Commission concluded that the social security industrial injuries scheme should remain essentially as it was, but that it should be extended and improved. The main proposals in this field are as follows:

(a) Improved earnings-related benefits. The major advantage which the Report recommends for those injured in accidents at work is entitlement to improved earnings-related benefits. For those entitled to the long-term disablement pension there would be an immediate right to the full earnings-related additional component of the new invalidity pension scheme, ${ }^{18}$ which other beneficiaries will acquire only after 20 years. ${ }^{19}$ The result of this would be an acceleration of entitlement to the increased benefits to be acquired by other beneficiaries later, the advantage diminishing each year until 1998.

(b) An earnings-related supplement to short-term injury benefit. The Report recommends that the benefit should comprise the existing flat rate benefit and an earnings-related supplement based on $33 \frac{1}{3} \%$ of earnings between the short-term lower earnings limit and $£ 30$, and $25 \%$ of earnings between $£ 30$ and the upper earnings limit. ${ }^{20}$ This latter represents an increase from the present $15 \%$. This would once again increase the differential between those injured at work (also extending it to those injured in a motor vehicle accident) and those injured or disabled otherwise. The Report also recommends that the supplement be paid without contribution conditions, ${ }^{21}$ adding a further differential, because contribution conditions are an essential prerequisite to a claim for non-industrial benefit.

(c) Partial disability. The Commission clearly felt that the present arrangements for dealing with partial incapacity for work (i.e. where a person is able to work but for reduced earnings only) were unsatis- factory. The present special hardship allowance provides some recompense for the loss but is far from satisfactory because of the low limit on the benefit payable and the complex conditions applicable to the award. ${ }^{22}$ Sir Robert Micklewait (the former Chief National Insurance Commissioner) suggested in his evidence to the Commission that the statutory provisions relating to this allowance required 'radical rethinking'. Having appeared sympathetic to this view, it seems strange that so little of the Report is given up to a discussion of this problem, especially as several members of the Commission visited Australia where the Woodhouse Commission intensively investigated this same problem. ${ }^{23}$ The Commission recommend that European provisions for compensating for partial incapacity should be studied with a view to introducing such a scheme here. Once again the Commission were prepared to venture beyond what they saw as their terms of reference, by suggesting that the problem was one which extended over the whole field of injury and sickness. While most people would agree that it is a wider problem, not restricted to those injured at work or on the road, it seems strange that in other areas the Commission were less prepared to go beyond their terms of reference or even to comment on the wider area.

(d) Widows and widowers. The Commission proposed the extension to widows under the work scheme (and also the motor vehicle scheme) of the earnings-related advantages they proposed for the non-fatally injured. Widows' pensions would, therefore, gain the benefit of the earnings-related supplement as if the deceased husband had been contributing to the new scheme for twenty years. ${ }^{24}$ They also recommend an increase in the earningsrelated supplement to the short-term widows' benefit in line with the adjustment to injury benefit. ${ }^{25}$ However, on the whole, the Commission felt that widows should be treated alike and recommended that, in future, provision for widows in the industrial injuries scheme should be harmonised with provision for other widows under the national insurance scheme. They suggest that the 'scaled benefit rates' currently payable to widows between the ages of 40 and 50 under the national insurance scheme should be applied to industrial widows also. (This provision was introduced in the National Insurance (Old Persons' and Widows' Pensions and Attendance Allowance) Act 1970 s.2, and is now in Social Security Act 1975 s.26(2) but was never made applicable to industrial injuries benefit.) Long-term pensions for widows benefiting under the industrial injuries scheme have a preference of 55p a week over pensions in the national insurance scheme. To aid 
harmonisation of the schemes the Commission recommend that this should be phased out and that the small pension ( $£ 4.59$ a week at January 1977 levels) payable to all widows in the industrial injuries scheme who do not qualify for a full-rate pension because of age or family circumstances, should also be phased out but that pensions currently in payment should not be withdrawn or reduced.26 As a further step towards equal treatment for all widows it is suggested 'that the Government should consider removing the contribution conditions for flat-rate widows' benefit under the national insurance scheme'. ${ }^{27}$ Widowers are to be favourably treated where the wife dies as a result of a work or motor vehicle accident. At present, benefit is payable only (1) where the death of the wife arose from an industrial cause and (2) if the husband is incapable of self-support. The Report recommends that the second condition be removed. ${ }^{28}$ Because the argument put for this change is the alteration in the work pattern of many families, and the realisation that many families rely on both incomes, it seems odd that the Commission did not suggest that a similar change ought to be made to the benefits payable to widowers whose wives died as a result of some other cause. While this would have been beyond the terms of reference as they were interpreted by the Commission, this reluctance to go beyond them was not present when they suggested the removal of the contribution conditions for widows under the national insurance scheme, nor in some of their other recommendations. Where a husband and wife jointly contribute to the family income by paying for the mortgage, rates etc. out of their joint income, the death of either can be a financial disaster for the other. For the widower who may have to pay for someone to look after the children after school, in the school holidays, or when he is absent from home due to his work, there will also be an extra financial burden if his wife, when alive, was able to cope with this, despite employment.

(e) The self-employed. In the Commission's view the self-employed have been unjustly treated hitherto, deserving compensation from a work accident as much as employed persons. It is recommended that the self-employed should become eligible for disablement benefit. Their unequal treatment is particularly marked as it is alleged that contributions by them to the national insurance scheme are not matched by the benefits available. Because of the repercusssions both for sickness benefit and retirement pensions, neither of which provide for earningsrelated benefit, it is proposed that, for the time being, benefits to the self-employed and their widows should be paid at a flat rate only. ${ }^{29}$ In view of the fact that the Report considered that many preferences should be retained or further increased for the employed person injured at work, as against his fellow-sufferer who is injured elsewhere or disabled through sickness, it is difficult to see why the possibility or desirability of an earnings-related element for the self-employed injured at work should not have been considered, even if this did place him in a preferential position as against his fellow-sufferer injured elsewhere or disabled through sickness. On their visit to New Zealand the Commission must have been made aware of the special problems the Accident Compensation Scheme there had to resolve to try to provide a just solution to the problems of the self-employed.

(f) Commuters. The Commission recommend (by a majority of one) that accidents on the way to and from work should be covered by the industrial injuries scheme. ${ }^{30}$ The main argument justifying this was the fact that $60 \%$ of them would be entitled to compensation under the proposed road accident nofault compensation scheme. However, in view of the fact that railway undertakings would become strictly liable, giving some possibility of a remedy to rail users (albeit with the problems of a court action instead of the more beneficial motor accident scheme) and the majority of people who travel to work do so by road, rail or on foot, the anomalies created by excluding commuting accidents would be slight compared with all the anomalies still left, or even introduced, were the Report to be implemented fully.

(g) Occupational diseases. The Commission recommended that an examination be made to see if there was any means of reducing the time taken for the prescription of occupational diseases. Where restrictive conditions operate for the prescription of certain occupational diseases it is recommended that these should be removed in accordance with the EEC Recommendation of 20 July 1966.31 The Commission also recommended that the mixed system of compensating occupational diseases should be adopted, so that the benefit would be payable, not only where disease comes within the prescribed list, but also where the claimant could prove that his disease was occupational in origin, and a particular risk of his occupation. ${ }^{32}$ It did not feel able to recommend that a special scheme should be set up for workers in the slate and other quarrying industries.

THE ROAD INJURIES SCHEME

The Commission recommend a 'no fault' compensation scheme for motor vehicle injuries based on the improved scheme proposed for work injuries, 
with rates of benefit at the same level. ${ }^{33}$ Special provision would be made in such a scheme for children and retirement pensioners, ${ }^{34}$ while nonearners would be entitled to the basic flat-rate benefits and disablement benefit for loss of faculty. ${ }^{35}$ It would be confined to injuries caused by motor vehicles and incurred on roads or other land to which the public has access.

\section{MEDICAL INJURY}

The Commission recommend that the progress of the no fault schemes in New Zealand and Sweden, which include compensation for medical accidents, should be studied and assessed, so that the experience could be drawn upon if it were ever decided to introduce a no-fault scheme here. However, for the time being they do not recommend such a scheme for the United Kingdom. ${ }^{36}$

\section{FINANCING OF THE SCHEME}

The Pearson proposals retain the existing sources of finance for employment injuries. With one dissentient it is recommended that the industrial injuries scheme should continue to be financed by earnings-related contributions from employers and employees, together with a contribution of $18 \%$ from general taxation. The increase in benefits is to come from increased contributions from employers only. ${ }^{37}$ The Pearson Commission give no arguments as to why employees' contributions should not be increased, but only that from employers. Commuting accidents would be financed from this source also. For road injuries they recommend that the scheme should be administered by the Department of Health and Social Security and that it should be financed by a levy of about $1 \mathrm{p}$ a gallon on petrol. ${ }^{38}$ One of the Commissioners dissented from this levy and suggested that a levy on insurance premiums was a superior method of finance.

There is one dissent on the method of finance proposed for work injuries, which states the case for risk-related premiums, ${ }^{39}$ and a similar one on that for road injuries. ${ }^{40}$ Where a premium is to be riskrelated, the question which must first be answered is whether the risk to be taken into account should be the risk of injuring someone or of being injured. Where the levy is on an employer, it can be only the risk of one of his employees being injured which is relevant, but it can be argued that a levy should take into account not only the risk of injury in that particular industry but also the risk of injury in that particular plant, something over which the employer has some control. This could be done by differential premiums in particular industries and by penalty and bonus premiums for particular plants. While these might be difficult to administer, and costly, they would at least provide some incentive to employers to be safety conscious. It can be argued that, in considering contributions by employees, not only should account be taken of the risk of being injured, but penalties and bonuses should also be applicable to encourage safety at work. This would be quite different from a scheme which penalised a worker for carelessness by not granting him any compensation. Again, one feels that the Commission could have spent some time profitably while they were in New Zealand in investigating the problems in the New Zealand system, the difficulties in introducing penalties there and in examining how the differential rates between industries were working.

As far as road injuries are concerned, the method of finance proposed by the Commission can also be criticised. Because cars vary so much in their petrol consumption there is little risk-relation in a petrol tax. Such a tax also penalises people who use their car a great deal (e.g. because they live in the country) yet there is little evidence that such persons are at greater risk of injuring either themselves or other people. If the risk which should be relevant is that of being injured, then passengers and pedestrians are also at risk and will not contribute at all to a petrol tax. Of all road users the motor cyclist is at greatest risk of injury (and because of this the levy for motor cyclists has recently been increased in New Zealand) yet under the Pearson proposals he will pay least towards the scheme. Where a vehicle is a Company car, the levy on petrol will effectively be paid by the Company and not the person at risk, the driver. The levy for buses and heavy vehicles will be paid by employers, and indirectly by the public. The New Zealand scheme of levy provides for the possibility of a levy on drivers as well as owners, but this has not yet been introduced there and they still have not solved the problem of risk-relation, in that there is no provision for bonus or penalty premiums although this could also provide some incentive for care on the road, even if not a very effective one. If it is felt that a levy should be related to the likely cost, and risk, of being injured, the scheme becomes very like compulsory insurance, the highest earners having to pay most. If the levy were related to the risk of injuring oneself or another it would be very difficult to assess this, but at least the disadvantage of the previous example would be absent. A highrisk driver from the point of view of causing accidents, even if he has no dependants and a low income, would pay more than a low-risk driver with a high income and several dependants, whereas in the previous example the reverse situation would apply, and it would be essential to have penalty premiums and perhaps bonus payments for those with good records, to counteract this. In the end, the 
method of financing which is chosen will have to be determined on policy grounds, and on this there will be much room for argument as to the most just method. The Pearson proposals neither bring out all the problems nor appear to have reached a very convincing solution to the problem of finance.

The Commission were not prepared to remove the tort action altogether and there certainly are problems to face if this were to be done. However, if one retains tort and introduces a system of no-fault compensation one has the problem of increasing the number of possible beneficiaries from the scheme but without making any savings from the abolition of the old scheme. Finance must then come from some new source, or else there must be an increase in the levies already paid, or a mixture of the two. The Commission has not given clear reasons for the choices made as to the sources of finance for the proposals, and at times appears not to have clearly examined the problem of who ought to pay for the improvements, with the exception of the dissenting Commissioner. Nor has it considered whether there should be penalties or bonuses within the scheme.

\section{Assessment of the Main Proposals}

The Pearson Commission faced a very difficult task in considering the problems inherent in our present system of compensating those who are injured. In the end, quite apart from the decision as to whether a country can afford to reform the law, a decision must be taken on how far collective responsibility for accidents or sickness should be adopted. Attitudes on the desirability of such a widespread change will differ and it is therefore not surprising, even if a little disappointing, that the Pearson Commission felt unable to do more than propose certain compromises. It was obviously concerned to make its proposals reasonably acceptable to the various pressure groups within Society, and it was probably realistic to do so. However, one wonders if it would not have been successful in wooing such groups, as was done by the Woodhouse Commission in New Zealand, had it put all the issues clearly before everyone in the Report.

The limitation which the Commission placed upon themselves by restricting their terms of reference made it impossible for them to suggest a radically new scheme like the New Zealand Accident Compensation Act or the Report of the National Committee of Inquiry into Compensation and $\mathrm{Re}$ habilitation in Australia, but it could, even within its own limits, have proposed a scheme which would have been capable of extension to other groups later.

The Commission recommend that the existing arrangements for compensating injured persons should all be retained, but that some of them should be improved or extended, while certain new categories should be added (e.g. road accident victims). The result of all this would be an incredibly complex system, each category having its own special conditions for entitlement, its own level of benefits, and its own methods of assessing such benefits. This could result only in an increase in administrative costs in total, and in overlapping categories with many demarcation problems arising. Some categories would have different machinery from others for both general administration and appeals.

It is ironic that the one thing on which the Commission seemed united was the fact that a system dependent on how an accident occurred (i.e. whether it was due to fault on the part of another person) was no longer adequate or appropriate, yet the very recommendations which they made to remedy this situation would result in a situation where it was equally important to ascertain how the accident occurred. Their proposals would also result in any person who was injured in an accident at work, or on the road, and who subsequently suffered illness, trying very hard to link the one with the other, to gain the extra financial benefits.

The Commission devoted Chapter 11 in the Report to 'Our Strategy' but it is difficult to find any clear objectives articulated here. It is obvious that the Commission was divided on many issues and one can sympathise with them regarding the difficulties which inevitably arose from this, as well as the differences of opinion which were inevitable in such a large body. The problem is certainly not an easy one to resolve, and one would be naive to imagine that it has an easy or clear-cut solution. Some members of the Commission clearly indicated that they basically disagreed with the philosophy of the tort system and hoped that it would eventually wither away, while others indicated that they did not feel that the social welfare philosophy could be a total replacement for tort, holding that tort and private insurance still had an important role in the field of accident compensation. The resulting Report was, inevitably with these divergent views, a compromise. Added to this was the problem for the Commission that, even if they could have found a more comprehensive and radical solution to the problem which would have appealed to all members of the Commission, such a solution would still have needed to gain the support not only of the Government, but of all the pressure groups within Society who would be affected by it. How far a Commission should take this into account is very difficult to decide, but it would be unrealistic to imagine that it could avoid being influenced to some extent by it, particularly as many of the groups with a strong view on the matter will have given evidence before 
the Commission. However, even with sympathy for the difficulties facing the Commission, one cannot but feel that the Report abounds with compromise and inconsistency, and has introduced further favoured groups for compensation without giving any real justification for compensating them rather than the groups not so favoured.

Few would argue that the present system is really adequate, but there are several possible ways of tackling the problem. One could improve the present system simply by trying to speed up the judicial process, but this would only tinker with the problem, not tackle it at its roots.

Alternatively, one could try to make a major reform in this area. One view frequently expressed is that it is better to make a start in reform by improving the position of employed persons who suffer accidents, and road accident victims, because they are already dealt with by the law, but inadequately, thereafter introducing new legislation for other groups not provided for at all. This may have been the philosophy behind the Pearson proposals. However, it is submitted that it is still necessary to justify this improvement, as a more pressing need than that of the others for whom no provision is yet to be made. Can a case really be made to justify compensating those injured in road accidents, but who at present receive no compensation (because they cannot prove fault on another's part) and compensating those injured in an accident at work, or on the way to work, yet not compensating a person suffering an accident outside these categories? The financial and other needs of the person and their family are identical, and once one jettisons the fault principle, the only justification for compensation must surely be that the person ought to be compensated in our Society because he and his family are in need of this. Is the housewife or child or retired person or unemployed person injured in an accident, other than a road accident, but unable to prove fault, less deserving of compensation, or less in need than when injured in a road accident?

An argument sometimes used to justify covering accidents at any time or in any place to employed persons is the avoidance of the determination in each case of whether a person sustained the injury 'in the course of his employment'. It is certainly true that this problem would vanish, but, unfortunately, another one would take its place. One can envisage a large number of cases in which a person would maintain that an illness from which he was suffering could be traced back to, or had been aggravated by, an accident suffered several years ago, some of the cases requiring considerable investigation, medical and otherwise. The only way to avoid such problems would be to cover accident and sickness.

An argument used to support the case for providing compensation for all persons injured in road accidents, even if other accident victims are less well provided for, is that motor accidents are more common, with the result that the public demands that compensation should be provided for such victims. ${ }^{41}$ Even if public clamour is greater for this reform than for a reform of compensation payable in respect of sickness or other forms of accident (and it is suggested that it may be the clamour of a few individuals together with the media, rather than the public at large), should not the determining factor be whether the one is justifiable as a more pressing reform than the other, not whether public clamour is greater for the one than the other? It has also been argued that English law already accepts liability without fault where special circumstances have been made out, ${ }^{42}$ but, as stated earlier, this is so in the field of personal injuries in only a few cases. The argument itself implies the need to make out a special case for such, yet no case has been made.

A further possibility is to compensate all accident victims, irrespective of the cause of the accident and of whether employed, but here again one can see injustice. It appears difficult to justify compensating the wage earner of a family which has suffered as a result of his being severely disabled in an accident (e.g. by a golf ball blinding him on the golf course, in a situation where he cannot prove fault) yet not compensating or compensating less well, the wage earner of a family when he is severely disabled as the result of a stroke suffered on the same day on the same golf course. Some people may well be accident prone just as others are sickness prone. The merits of the one are no less than the other; each is unfortunate in a similar way. Of course, it might be argued that sickness is peculiar to the individual, a problem concerned with his own anatomy, a misfortune, but something with which his neighbours or the State cannot be expected to assist. Yet could it not also be said that an accident is personal, in a sense, in that another person with a different reaction time might have avoided it? Could it not be argued that, since there is now some medical evidence to suggest that our total environment is at least partly responsible for some diseases, the State should have neither more nor less responsibility for assisting persons disabled in this kind of 'accident' than persons disabled in accidents in the more usual sense of the word?

If one is just tinkering with the problem, then it is justifiable to continue to provide for the categories already provided for, but by improved measures, and even to extend such categories very slightly for administrative and social advantage. If, however, one is making a fresh start, or at least is providing 
more comprehensive cover than before, it is necessary to look not only at the categories already provided for, and to extend them slightly, but also to look at the philosophy supporting provision for these categories but not for others. The proponents of cover for accidents but not for sickness tend to act as if, once one jettisons the fault concept for accidents, it remains within the field of tort law, but this is not really so, for with fault irrelevant the justification must surely be on need, which brings it much more within the realm of social security. Once that is seen it becomes very difficult to exclude others whose need is similar, or to differentiate them by giving them less adequate compensation.

The Woodhouse Commission in New Zealand proposed cover for accidents to all persons, employed or not (and this was ultimately implemented in the Accident Compensation Act 1972 as amended by the Accident Compensation Amendment (No. 2) Act 1973). It did so on the basis of a philosophy that the community had a responsibility for such accidents. It admitted the difficulty of differentiating accident victims from sick persons, and did not attempt to justify the one, simply stating that because of the difficulties of costing compensation for sickness, caused by lack of availability of satisfactory statistics, and because an investigation into this was being made by another body, advancement by two smaller steps rather than one larger one was preferable. It is unfortunate that the Pearson Commission with all the statistical resources at its disposal interpreted its terms of reference so narrowly as not to include other accidents or sickness.

The final possibility would be not only to cover all accidents, but also to compensate equally all victims of illness. Even if this could not be achieved immediately, it might be possible to make such alterations to our present system as would make the eventual goal of a comprehensive system covering all forms of sickness and disability easier to achieve. The National Committee of Inquiry in Australia was prepared to propose this as the important goal in reform of this area of the law, and put up forceful arguments as to why this not only should be the goal but could, on the basis of statistics produced by them, be achieved. When the Australian Labour Government was dismissed in November, 1977, a National Rehabilitation and Compensation Bill was about to be introduced into Parliament, incorporating most of the changes recommended by the Senate Committee which examined the original Bill attached to the Woodhouse Commission Report. This new Bill limited compensation to accidents only, showing just how difficult it is to convince Governments of the justice of compensating victims of sickness as well as accident victims. In February
1977, Mr Whitlam introduced the Bill as a Private Member's Bill but the outlook even for this limited reform seems poor at the moment.

The Pearson Commission appear to have viewed the first choice within the second alternative as the most appropriate one, and yet have nowhere made out a case justifying the favoured treatment of these particular groups. If they were unable to justify them and intended that they should simply be chosen for special favour now, but with a view to the other less favoured groups being included later, they should have clearly stated their desire to see such an extension, and planned the reforms they proposed in such a way that they could have been extended easily later. There are several places in the Report where the Commission do show an awareness of the merits of more comprehensive cover and a wider eventual goal. They were convinced that the social security system should be the primary source of compensation for injured persons, and this system has in recent years been moving towards the alleviation of the consequences of disability, irrespective of cause. ${ }^{43}$ They also proposed a new benefit for severely handicapped children and suggested that widows should be treated equally, both forms of benefit to be based on need rather than cause. However, this was marred by their special recommendations for vaccine-damaged children.

As far as eventual extension to other categories of the recommendation is concerned, that appears rather unlikely in the foreseeable future. By selecting for special and generous compensation certain categories of injured and disabled persons, according to the cause of their incapacity, and giving them a high level of earnings-related benefit together with disablement benefit for loss of faculty, the Commission have made it less likely that this will be extended in the future. They have thrown away the concept of fault for certain accidents, but have given benefits not too dissimilar from those which would be given to a successful plaintiff in a tort action if he could prove fault, at least if he was not a very high wage-earner. By so doing they have made it much less likely that a Government will be persuaded to give equally generous compensation to sickness victims who have never had the possibility of being able to sue successfully for such in the law of tort.

It seems inevitable that compensation, at the level at which it is awarded to a plaintiff successful in proving fault, could not be given to all and that there must be some limitation to the amount of compensation payable from a State fund. This then raises the problem of whether the tort action should be retained to enable the person still able to prove fault to gain a complete indemnity. The Pearson Commission felt, on balance, that it should be so 
retained, at least for the present, but this immediately raises a problem. The Woodhouse Reports, in both New Zealand and Australia, and the academic writings on the problem of compensation all seem united in that to widen the scope of compensation requires extra funds to be available, and that the only place from which savings can easily come is administrative costs in the tort action if such compensation is abolished. A policy question is then immediately raised. Is it better that all of a group should be able to recover something, if injured (or suffering from sickness, if that were to be covered also) even if some recover less than they do at present? The Commission did not have to face this problem, as they retained the tort action, but it would certainly have to be faced if the scheme were to be extended to cover other groups who were disabled. It will be very interesting, if the Pearson proposals are implemented, to see just how costly will be the administration of the mixed scheme of tort and social security which they propose.

In a field where it is widely felt that some reform is long overdue the Commission can rightly claim that their proposals in aggregate would lead to compensation for injured persons and their dependants being 'appreciably improved and extended' ${ }^{44}$ The Commission express the hope that, in the future, the close relation between compensation for the injured and bereaved provided by the law of tort and the social security system can be more clearly seen, with a shift in emphasis away from tort toward social security, the latter becoming the principal means of compensation, tort simply supplementing it. This is certainly one of the more important aspects of the report. For too long the two schemes have been seen in isolation, although as has been said by Elliott and Street (1968) ${ }^{45}$ : 'It is no exaggeration to state that the present tort system is endurable at all, only because of the social security system. Although the tort system purports to be independent of the social security system it would be seen to be an utter failure if social security did not prop it up at every stage.' However, whether the proposals 'would result in a better balance in the distribution of the funds devoted to compensation for personal injuries and would give greater help to those who most need it', as is claimed by the Commission, is more arguable. The proposals certainly improve the present system, but one can argue that it does little more than tinker with the problems, improving a bit here and there but without looking at the whole problem of compensation in its wider context. Although the Report talks of the desirability of coordinating tort and social security, the Report itself often fails to do this, even where an opportunity presents itself. It tends to accept the present position in certain cases without analysing them in the light of a new coordinating policy. Nowhere in the Report is there a discussion of whether damages should be available for a young childless widow, capable of earning her own living and at present able to obtain a large Fatal Accidents award. Nowhere is there a discussion of whether there ought to be a reconsideration of the present six months' pension, which is what the same widow would receive under the social security scheme, if unfortunate enough to have to rely on it. The Report conceded that common law damages are over-generous in minor cases and too low in major cases, but fails to comment on the fact that the disability benefits under the industrial injury scheme (a scheme the benefits of which they propose to extend to victims of road accidents) can be criticised in the same way. Disability benefit for those with serious injuries is not proportionately greater than that for minor injuries. In addition, the person with a $20 \%$ disability or less will usually find that this has only a small effect on his life and that of his family, while the person with a $70 \%$ disability or more may have to adapt to a completely new life-style, because this will almost certainly have a devastating effect on himself and his family. As the more serious disabilities are less common than the more common minor injuries, it would have been very easy to have slightly reduced the compensation for minor injuries to increase the benefits for those with serious injuries who need it most.

The Commission clearly accepted that compensation should be paid irrespective of fault in certain cases, yet they themselves categorise people as entitled to support, not on the basis of whether they have suffered an injury or disability, and are in need of compensation, but according to the circumstances giving rise to that disability. They do not justify the preference granted to work and road victims. With regard to work victims, it clearly was intended to avoid the trade union movement feeling that members injured through work, whether due to the fault of the employer or not, might receive lower benefit, especially if the scope of the tort action were to be reduced. This argument does not however apply to road accident victims who, hitherto, had no such remedy except in tort, and no preferential treatment. This might well cause resentment to the groups not so favoured, especially as their benefits will remain subject to contribution conditions, unlike the favoured groups.

Perhaps the greatest inconsistency in the whole Report can be seen in the discussion on vaccinedamaged children. In paragraph 1406 the Commissioners state that they do not think it right to distinguish one severely disabled child from another, and that vaccine-damaged children should be con- 
sidered together with other severely disabled children, irrespective of the cause of disablement. In the following paragraph they state: 'For those children who can be shown to have been victims of vaccine damage, we consider that there is a case for an additional remedy in the field of tort.' They go on to recommend that the Government or local authority concerned should be strictly liable in tort for severe damage suffered by anyone (adult or child) as a result of vaccination recommended in the community interest. It almost looks as if the two paragraphs were written by two separate Commissions, so inconsistent do they appear. This recommendation has been accepted by the Government.

\section{Conclusions}

The Pearson Report has performed a valuable service in authoritatively stating the case for some reform in our present law of tort, as far as accident victims are concerned. It has clearly underlined its inadequacies and how important our present social security system is for accident victims. Perhaps the greatest achievement of the Commission has been the clear way in which it has enunciated its view that, for too long, the law of tort and the social security system have been seen as separate and distinct, when the latter has been indispensable to the former. The Report has, at times, itself appeared not to see how the schemes could be harmonised, but the clear statement to the effect that it is no longer possible to avoid integrating the schemes marks a step in a new direction which was long overdue. No one who reads this Report carefully can possibly fail to realise the shortcomings of our present arrangements for compensating victims of accidents.

While having considerable sympathy for the Commission in its very difficult task, one cannot but wish that it had spent more time on a discussion of the ultimate goal for compensation for disability. So often it appears to have seen many of the problems and inconsistencies in the present law and yet has failed to go beyond to discuss clearly where the possible remedies lie. Because of the number of compromises made, the system proposed, while remedying certain of the defects, abounds with inconsistencies itself and continues to pay far more attention than is justified to granting preference for particular groups. The result is that one's entitlement to benefit would still depend, to a large extent, not on whether one had suffered some disability, but on how this had been caused. Many of the victims not specially favoured in the Pearson Report will have to await another Commission or Committee of Inquiry before their case is stated.
The Report itself is a bundle of compromises but one can have sympathy with why this should be so. Despite this, the Report is still a landmark, and while it cannot, taken by itself, be a step in the direction of compensation for all forms of disability irrespective of cause, it may indirectly lead to this. If many of its proposals are implemented and the fault principle is 'put to sleep', even if not killed outright, a new philosophy appropriate to the proposals may arise, that victims of disability are entitled to compensation because of their need and not because of another's fault. Should this happen, even if initially to favoured groups only, the justice of the case of the remaining victims must become apparent. A compromise today perhaps but, one hopes. a leap into the future tomorrow.

\section{References}

(All paragraph and chapter references are to Volume I of the Pearson Report.)

${ }^{1}$ The Report of the Royal Commission on Civil Liability and Compensation for Personal Injury (1978) Cmnd. 7054.

Vol. I, Report, Vol. II, Statistics and Costings, Vol. III, Overseas Systems of Compensation. HMSO, London

${ }^{2}$ Para. 1

${ }^{3}$ Para. 3

${ }^{4}$ Report on Compensation for Personal Injury in New Zealand, December 1967. Government Printer, Wellington, New Zealand 1972. (Also known as the 'Woodhouse Report')

5Paras. 299-306

${ }^{6}$ Para. 482

'Paras. 573 and 600

${ }^{8}$ Para. 388

${ }^{9}$ See dissent to the recommendation paras. $448-464$

${ }^{10}$ Chapter 15

${ }^{11}$ Paras. 1406 and 1407

${ }^{12}$ Chapter 22

${ }^{13}$ Para. 1341

${ }^{14}$ Para. 1186

${ }^{15}$ Chapter 31

${ }^{18}$ Para. 1666

${ }^{17}$ Para. 1660

${ }^{18}$ Paras. 804-5

${ }^{19}$ Social Security Pensions Act, 1975, ss. 6 and 13

${ }^{20}$ Para. 808

21Para. 809

22See para. 816 and 817 and Annex 6

${ }^{23}$ Report of the National Committee of Inquiry on Compensation and Rehabilitation. Parliamentary Paper 100. The Government Printer of Australia, Canberra (1974), paras. $375-405$

${ }^{24}$ Para. 841

${ }^{25}$ Para. 842

${ }^{26}$ Para. 840

${ }^{27}$ Para. 844

28Para. 846

29Paras. 851-856

${ }^{30}$ Para. 867

31 Paras. 877-879

32 Paras. 880-887

${ }^{33}$ Paras. 1004 and 1015

${ }^{34}$ Paras. 1021-2 and 1023-4

35Para. 1020

${ }^{36}$ Chapter 24 
${ }^{37}$ Para. 904

${ }^{38}$ Paras. 1051-1054

39Paras. 940-948

${ }^{40}$ Paras. 1093-1102

${ }^{4}$ D. W. Elliott and H. Street (1968). In Law and Society, Road Accidents, p. 249. Penguin Books, Harmondsworth
${ }^{42}$ Ibid, p. 251

${ }^{43}$ Report on Security Provision for Chronically Sick and Disabled Persons 1973-74, H.C. 276

44Para. 1732

${ }^{45}$ D. W. Elliott and H. Street, Op. cit., p. 247

\section{The August 1979 issue}

\section{THE AUGUST 1979 ISSUE CONTAINS THE FOLLOWING PAPERS}

Fatigue in industry E. GRANDJEAN

Mortality of chrysotile asbestos workers at the Balangero Mine, Northern Italy G. F. RUBINO, G. Piolatto, M. L. NeWhouse, G. SCANSETti, G. A. ARESINI, AND R. MURRAY

Thickening of pulmonary interlobar fissures: exposure-response relationship in crocidolite and amosite miners A. SOLOMON, L. M. IRWIG, G. K. SLUIS-CREMER, R. GLYN THOMAS, AND R. S. J. DU TOIT

Mortality in gold and coal miners in Western Australia with special reference to lung cancer B. K. ARMSTRONG, J. C. MCNULTY, L. J. LeVITT, K. A. WILLIAMS, AND M. S. T. HOBBS

The relationship between coal rank and the prevalence of pneumoconiosis J. G. BENNETT, J. A. DICK, Y. S. KAPLAN, P. A. SHAND, D. H. SHENNAN, D. J. THOMAS, AND J. S. WASHINGTON

Bronchoconstriction in potroom workers M. šARIĆ, E. ZUŠKIN, AND M. GOMZI

Lung function in sisal ropemakers M. D. BAKER, L. M. IRWIG, J. R. JOHNSTON, D. M. TURNER, AND B. N. BEZUIDENHOUT
A clinical survey of paraquat formulation workers J. K. HOWARD

Amount and distribution of fume contaminants in the lungs of an arc welder post mortem PIRKKOLIISA KALLIOMÄKI, S. SUTINEN, V. KELHÄ, EEVA LAKOMAA, V. SORTTI, AND SIRKKA SUTINEN

Partition coefficients of some aromatic hydrocarbons and ketones in water, blood and oil AKIO SATO AND TAMIE NAKAJIMA

The time course of mandelic and phenylglyoxylic acid excretion in workers exposed to styrene under model conditions H. K. WILSON, J. COCKER, C. J. PURNELL, R. H. BROWN, AND D. GOMPERTZ

Carboxyhaemoglobin levels in workers in Leicestershire garages G. R. KELMAN AND T. J. DAVIES

Donald Hunter-the first Editor of the British Journal of Industrial Medicine R. S. F. SCHILLING

Book reviews

Notices

Information section

Copies are still available and may be obtained from the PUBLISHING MANAGER, BRITISH MEDICAL ASSOCIATION, TAVISTOCK SQUARE. LONDON WC1H 9JR, price $£ 4.25$ (USA \$9.20), including postage 